\title{
Attitudes of Primary Education Students in Slovenia and Slovakia Towards the Constructivist Approach to Primary Science Education
}

\author{
Vlasta Hus (Corresponding author) \\ Professor, dr., University of Maribor, Faculty of Education \\ Koroška 160, 2000 Maribor, Slovenia \\ Tel: +38622293600Ｅ-mail: vlasta.hus@uni-mb.si
}

\begin{abstract}
Boris Aberšek
Professor dr., University of Maribor, Faculty of Natural Science and Mathematics

Koroška 160, 2000 Maribor

Tel: +38622293752Ｅ-mail: boris.abersek@uni-mb.si
\end{abstract}

Polona Jančič

Postgraduate student at University of Maribor, Faculty of Education

Koroška 160, 2000 Maribor

Tel: +38622293755Ｅ-Mail: polona.jancic@gmail.com

Received: April 10, 2014 Accepted: May 28, 2014 Published: July 23, 2014

doi:10.5296/jet.v1i2.6018 URL: http://dx.doi.org/10.5296/jet.v1i2.6018 


\section{Abstract}

The constructivist approach emphasizes the active role of the pupil in the educational process and his/her ability to construct new knowledge based on experience and previously acquired knowledge. The presented research is aimed at investigation of primary education students' attitudes towards constructivism and whether there are any differences between Slovak and Slovene students in this context. Study programs in both countries have their own specifics and emphasize different aspects of teaching and learning. Therefore, the study plans of the primary education program in both education faculties were taken into consideration. Q method was used as the research method, which enables objective discovery of individuals' notions of a certain research problem. The research revealed that most of the students have a positive opinion about constructivism as a teaching approach. Some education areas show a Slovak and Slovene students have a different attitude towards constructivism. The groups have a distinctively different opinion regarding the role of the teacher, group work and the use of experiments in class.

Keywords: primary science education, constructivism, Slovakia, Slovenia, students' attitudes

\section{Introduction}

The modern educator must be self-directed, creative, and innovative (Šorgo et al., 2012), and teacher education should enable students as prospective teachers to become creative and innovative through analysis, conceptualizations, and synthesis of prior experience to create new knowledge (Lamanauskas, 2007). The educator's role, especially in science education, is to guide the students during heuristic solving of ill-defined problems by enabling quested learning to modify existing knowledge and allow for creation of new concepts. The learning goals must be oriented toward the highest levels of learning, such as heuristic problem-solving, metacognitive knowledge, creativity, and originality, which calls for new methods and strategies of education (Science Education in Europe, 2011). Among the most promising methods and strategies for higher-order thinking and acting are those based on constructivism, especially social constructivism.

Social constructivism is a sociological theory of knowledge that applies the general philosophical constructivism in social settings, wherein groups construct knowledge for one another, collaboratively creating a small culture of shared artifacts with shared meanings. When one is immersed within a culture of this sort, one is learning continuously how to be a part of that culture on many levels. Its origins are largely attributed to Lev Vygotsky (1978).

Social constructivism or socioculturalism encourages the learner to achieve his/her version of the truth, influenced by his or her background, culture or embedded worldview. Historical developments and symbol systems, such as language, logic and mathematical systems, are inherited by the learner as a member of a particular culture and these are learned throughout the learner's life. Young children develop their thinking abilities by interacting with other children, adults and the physical world. From the social constructivist viewpoint, it is thus important to take into account the background and culture of the learner throughout the learning process, as this background also helps to shape the knowledge and truth that the 
learner creates, discovers and attains in the learning process (Wertsch, 1997).

Constructivism is a major referent in education, although it has been understood in various ways as a learning theory, a philosophical stance on human knowledge and an approach to social enquiry. In terms of informing teaching, constructivism has variously been seen by different authors as a basis for progressive, mainstream or failed approaches to pedagogy. Constructionism (constructionist learning) is a constructivist learning theory whereby individual learners construct mental models to understand the world around them. It states that building knowledge can happen most effectively when people are also active in making tangible objects in the real world. In this sense, constructionism is connected with experiential learning, and builds on Jean Piaget's epistemological theory of constructivism (Cakir, 2008).

Constructionist learning involves students drawing their own conclusions through creative experimentation and the making of social objects. The constructionist teacher adopts a mediational role rather than adopting an instructionist position. Teaching "at" students is replaced by assisting them to understand - and help one another to understand-problems in a hands-on way (Papert, 1980). Papert has been a keen advocate of bringing information technologies into the classroom. His "new" idea was that from constructivist theories of psychology we take a view of learning as a reconstruction rather than as a transmission of knowledge. Then we extend the idea of manipulative materials to the idea that learning is most effective when it is part of an activity which the learner experiences as constructing a meaningful product. Papert's ideas became well-known through the publication of his book Mindstorm: children, computers, and powerful ideas (1980). He likened learning to living in a "mathland," where learning mathematical ideas is as natural as learning French while living in France.

Hickman, Neubert, and Reich (2009) observed that "constructivists do not look for copies or mirroring's of an outer reality in the human mind", but instead they rather see humans as "observers, participants, and agents who actively generate and transform the patterns through which they construct the realities that fit them." Contemporary psychologist Jerome Bruner, relying in part on the ideas of constructivists like Vygostsky, asserted that all reality is a narrative construction in the imagination of individuals (1980).

Constructivism has also been considered as a dominant paradigm, or research programme, in the field of science education. The most useful and promising constructivist learning theory which can be applied in a classroom setting is known as problem-based learning. Problem-based learning is a method which allows students to learn about a subject by exposing them to multiple problems so they are able to construct their understanding of the subject through these problems. This kind of learning can be very effective for mathematics and science where students try to solve problems in many different ways which allow their brains to be stimulated (Hmelo-Silver \& Barrows, 2006) but is rarely included in regular teaching practice (Šorgo \& Kocijančič, 2011). There are different types of instructional strategies which make problem-based learning more effective (Wilson, 1996): 
1. Try to relate all the learning activities for the learner to a larger task. This is important because it allows students to see the connection to the activities that can be applied to many aspects of life. As a result, the learner will find the materials and activities they are doing useful.

2. The learner needs to be supported to feel that they are beginning to take ownership of the overall problem.

3. An authentic task should be designed for the learner. This means that the task and the learner's cognitive ability must match the problems to make learning valuable.

4. Allow reflection on the content being learned so the learner can think through the process of what they have learned.

5. Allow and encourage the learners to test ideas against different views in different contexts.

This research describes one version of constructivism: that which is informed by findings from both cognitive science and from educational studies exploring learners' thinking about curriculum topics and about classroom processes. A key concept here is the way in which new learning is contingent on the features of the learner, the learning context and the teaching. This version of constructivism (which has been widely embraced) offers a theoretical basis for designing effective pedagogy that is accessible to classroom teachers.

Current research is based on assumptions that constructivism understood this way certainly offers the basis for learner-centred teaching. One feature of this approach is that it does not adopt doctrinal allegiance to particular levels of teacher input (as can be the case with teaching through discovery learning or direct instruction) but rather the level of teacher guidance (1) is determined for particular learning activities by considering the learners and the material to be learnt; (2) shifts across sequences of teaching and learning episodes, and includes potential for highly structured guidance, as well as more exploratory activities. When understood in these terms, constructivism provides a sound theoretical basis for informing teaching at all levels and in all disciplines.

Students of primary education are also familiar with the constructivism approach to primary science education and attitudes of those in Slovenia and Slovakia towards constructivist approach of a primary science education are described below.

\subsection{Research Purpose}

The purpose of the presented research was to compare primary school students' attitudes toward different conceptions of education with a focus on constructivism and on the basis of such analysis develop a more effective methodology of teaching in their faculty of education. From the study programs it is evident that students do gain knowledge about constructivism. The question of interest was: what are students' attitudes towards syllabuses containing constructivist ideas? Our interest was also in finding differences in their ranking of specific elements of constructivism.

The second most important task of the research was to investigate differences between the attitudes of Slovak and Slovene students. Both groups have their own individual educational programme of corresponding studies. Those differences along with the study year difference 
were taken into consideration. We tested students who we predicted from the study programme would already have some knowledge about constructivism. It was expected that differences between different concepts of education would be recognizable. Predicted differences between countries can be assigned to the specifics in study programs. Nonetheless those differences should not be too divergent since constructivism is intensively incorporated in both study programs.

\section{Methodology of Research}

In the search for subjective opinions, perceptions and attitudes we selected a method which could analyze subjectivity in an objective way. Q-method was chosen as the most appropriate method for a research investigating subjective attitude. It is designed to examine qualitative aspects of the research theme. It combines the strength of qualitative and quantitative research traditions and provides a bridge between the two (Brown, 1996). Q-methodology is also a powerful tool for analyzing opinions, perceptions and attitudes in an objective way. The study of people holistically, focusing on their qualitative and subjective sides, requires a different investigational approach (Wigger \& Mrtek, 1994). The instrumental basis of Q-methodology is the Q-sort technique, which conventionally involves the rank ordering of a set of statements from agree to disagree (Brown, 1996).

\subsection{Methods and Sampling}

Fifteen senior students of primary education at the Faculty of Education in Maribor, Slovenia, and 15 second-year students at the Faculty of Education in Trnava, Slovakia, participated in the research. The testing was performed in December 2007 and January 2008. Study programs of both faculties have their own specific emphasis on aspects of teaching and learning. Therefore the study plans of the primary education programs of both faculties were taken into consideration. It was essential to choose appropriate groups of students for the purpose of the research. From both faculties, we chose groups of students who should already have gained knowledge about constructivism. The courses the students followed in their syllabuses which could influence their attitudes to implementation of constructivism in primary education are listed and further analyzed below.

\subsubsection{Slovenia:}

Table 1. Subjects that might affect Slovene respondents' attitudes

\begin{tabular}{|l|l|l|}
\hline Subject & Year & Hours \\
\hline Science (biology, chemistry, physics) & I. & 180 \\
\hline Educational psychology & II. & 90 \\
\hline $\begin{array}{l}\text { Didactics of nature, science, technology and social studies with traffic } \\
\text { education }\end{array}$ & III. & 135 \\
\hline $\begin{array}{l}\text { Didactics of nature, science, technology and social studies with traffic } \\
\text { education }\end{array}$ & IV. & 75 \\
\hline
\end{tabular}




\subsubsection{Slovak Republic:}

Table 2. Subjects that might affect Slovak respondents' attitudes

\begin{tabular}{|l|l|l|}
\hline Subject & Year & Hours \\
\hline Educational theories & I. & 24 \\
\hline Educational psychology & I. & 36 \\
\hline Somatic development of children and youth & I. & 36 \\
\hline Nature and social studies in preschool education & II. & 72 \\
\hline
\end{tabular}

In both tables it can be seen that Slovak students had less opportunity to study constructivism, since the number of study hours is lower, but it must be taken into consideration that they were only in their second year. After accurate review of their study programs, it was established that the emphasis on constructivist learning is made in their second year in the subjects of nature and social studies in preschool education. The curriculums of the different subjects suggest that these Slovak subjects can be compared to the Slovene subject of didactics of nature, science, technology and social studies with traffic education. Students learn how to teach these topics in the classroom.

Furthermore, research and problem-solving, group work and learning collaboration, dialogues, educational conversations and construction of knowledge are all covered in these subjects. All the above subject components constitute basic applications of constructivist ideas in teaching and learning. For all the above reasons the two groups were expected to have some knowledge about constructivism and therefore were assumed to be capable of defining their attitude towards constructivism.

Participants were chosen randomly from the population of Slovenian students in the senior year and from Slovak students in the second year. They were tested during their practical exercises at the faculties.

\subsection{Q-Methodology Items and Procedure}

We devised 80 statements describing the different attitudes of primary teachers to different educational conceptions. All the statements are marked by a specific number. Those which do not stimulate teaching by the principles of constructivism have a lower number. Statements about teaching based on the principles of constructivism are marked by a higher number.

Table 3. Sorting the 80 statements into value categories

\begin{tabular}{|l|l|l|l|l|l|l|l|l|l|l|l|}
\hline Category & 0 & 1 & 2 & 3 & 4 & 5 & 6 & 7 & 8 & 9 & 10 \\
\hline Number of statements & 3 & 4 & 6 & 10 & 11 & 12 & 11 & 10 & 6 & 4 & 3 \\
\hline
\end{tabular}

For the purpose of avoiding respondent to sort all of the statements into middle category, which could mean he/she is undefined, we used the number of statements predicted in each category. It was important that the respondents expressed their attitude clearly, which is why we required them to sort the statements not into 80 values but only 11 . 
Statements strongly endorsed by respondents were ranged in categories with higher values and statements which attracted a much lower level of agreement were ranged in categories with lower values. For the Q-type series we chose that used by Kristina Žoldošova (2008).

\section{Results}

Data analysis was divided into two major categories. First, we performed basic analyses of the highest and lowest ranked statements by group. For more effective conclusions we also calculated standard deviation. With these basic analyses we established each group's attitudes toward constructivism. Second, we upgraded our newly acquired data with factor analysis, searching for correlations of respondents' attitudes. It was important to investigate correlations since one of our main research questions was whether there were any significant differences between Slovak and Slovene student groups. Finally, factor analyses answered our question about students' attitude towards a constructivist approach to primary science education.

\subsection{Basic Analysis}

\subsubsection{Slovak Group}

In the first group of respondents, the Slovak group, we searched for five statements that were ranked highest and five that were ranked lowest. When there were several statements with the same average all statements were written in the tables.

Table 4. Five highest ranked statements in Slovak group of respondents

\begin{tabular}{|l|l|l|l|}
\hline Statement & $\begin{array}{l}\text { Predicted } \\
\text { value } \\
\text { category }\end{array}$ & Mean & $\begin{array}{l}\text { St. } \\
\text { deviation }\end{array}$ \\
\hline $\begin{array}{l}\text { 42. To support children's fantasy and curiosity is as } \\
\text { important to support cognitive development. Fantasy and } \\
\text { curiosity foster free thinking. }\end{array}$ & 8 & 8.133 & 1.552 \\
\hline $\begin{array}{l}\text { 5. If it is possible to demonstrate any new knowledge by } \\
\text { offering object lessons, a better way to do this is a } \\
\text { demonstration by the teacher. }\end{array}$ & 7.533 & 1.457 \\
\hline $\begin{array}{l}\text { 46. Knowledge built on the basis of own experimental } \\
\text { activity is more stable in comparison with that built on the } \\
\text { basis of secondary information sources. }\end{array}$ & 5 & 7.400 & 2.293 \\
\hline $\begin{array}{l}\text { 59. Primary science teachers should pay attention not only } \\
\text { to pupils' knowledge but also to the relations between } \\
\text { particular information. Children should have a chance to } \\
\text { explain the phenomena they observe every day. }\end{array}$ & 7 & 7.400 & 1.183 \\
\hline $\begin{array}{l}\text { 60. The integration of knowledge which children obtain at } \\
\text { school with knowledge they obtain in everyday life is } \\
\text { especially important, because children can better } \\
\text { understand. The result is that they are more easily able to } \\
\text { make an effort when it is needed. }\end{array}$ & 7 & 7.267 & 2.764 \\
\hline
\end{tabular}


Table 5. Five lowest ranked statements in Slovak group of respondents

\begin{tabular}{|l|l|l|l|}
\hline Statement & $\begin{array}{l}\text { Predicted } \\
\text { value } \\
\text { category }\end{array}$ & Mean & St. deviation \\
\hline $\begin{array}{l}\text { 19. Development of imagination is important for } \\
\text { esthetically-oriented subjects. Science education calls } \\
\text { mainly for development of factual thinking. }\end{array}$ & 3 & 1.800 & 1.821 \\
\hline $\begin{array}{l}\text { 1. Learning is more effective when teachers explain to } \\
\text { pupils what they need to know. }\end{array}$ & 0 & 1.933 & 2.052 \\
\hline $\begin{array}{l}\text { 2. Frontal teaching is very effective for quality } \\
\text { learning, because a teacher can offer pupils a lot of } \\
\text { new knowledge in short time. }\end{array}$ & 0 & 2.333 & 2.193 \\
\hline $\begin{array}{l}\text { 8. Pupils learn more when they learn individually. } \\
\text { 27. I cannot easily see a use for PC, internet, } \\
\text { encyclopedias and similar information sources in } \\
\text { contemporary primary science education. }\end{array}$ & 4 & 2 & 2.333 \\
\hline $\begin{array}{l}\text { 30. I would like to change only one thing on the } \\
\text { contemporary primary education, the funding (of } \\
\text { schools and teachers). }\end{array}$ & 4 & 1.589 \\
\hline $\begin{array}{l}\text { 65. Pupils do not need to learn facts, but they have to } \\
\text { be able to find them in various information sources. }\end{array}$ & 7 & 2.533 & 2.031 \\
\hline $\begin{array}{l}\text { 78. A pupil's previous experience influences their } \\
\text { perception of new stimuli. A teacher cannot easily } \\
\text { change this. }\end{array}$ & 10 & 2.232 \\
\hline
\end{tabular}

Considering all the above categories we can conclude that even though there were some differences in group opinions, the most highly ranked statement is statement number 42 . Statement 42 concerns fostering children's imagination and curiosity to support their cognitive development. The next most positive attitude of this group was towards experimental activity, field learning and learning in everyday situations. They agreed that it is important to integrate knowledge gained from everyday situations with knowledge gained by school books and teachers' explanations. They have an especially negative attitude towards frontal teaching and individual learning. Given the highest-ranked statements it was expected that statements which emphasized individual learning and frontal teaching would be ranked low. Statement number 78 was surprisingly ranked low. It was expected to be ranked higher because statement number 46 , which had some similar points to number 47 , was ranked quite high. In students' opinion pupils should learn facts and not only how to find information. This group also disagreed with the statement about the usage of innovative technology. We can assume that they have considerable experience with media and are in favour of the use of ICT in primary education science. 
For more accurate analyses we calculated and presented standard deviation as well. Standard deviation has an effect on average values and their interpretation. Knowing standard deviation values we can make an assumption about group dynamics and group homogeneity.

The highest standard deviation is presented in statement number 25, which is: Primary pupils are able to obtain a great amount of knowledge. Often, however, they are unable to make the effort needed for knowledge acquisition. That is why motivation and repetition are so important. The chosen educational method is less important.

Table 6. Ranked statement number 25

\begin{tabular}{|l|l|l|l|l|l|l|l|l|l|l|l|l|l|l|l|l|l|l|}
\hline Respondents & 1 & 2 & 3 & 4 & 5 & 6 & 7 & 8 & 9 & 10 & 11 & 12 & 13 & 14 & 15 & PV & M & SD \\
\hline Ranked values & $\mathbf{3}$ & $\mathbf{4}$ & $\mathbf{1 0}$ & $\mathbf{6}$ & $\mathbf{4}$ & $\mathbf{0}$ & $\mathbf{5}$ & $\mathbf{9}$ & $\mathbf{1 0}$ & $\mathbf{3}$ & $\mathbf{1}$ & $\mathbf{3}$ & $\mathbf{1 0}$ & $\mathbf{4}$ & $\mathbf{7}$ & 3 & $\mathbf{5 . 2 6 7}$ & $\mathbf{3 . 2 8 3}$ \\
\hline
\end{tabular}

Legend 1: M...mean, PV...Predicted value, SD...Standard deviation.

It can be seen that students had different attitudes towards this statement and were not homogeneous enough. We can assume that they had not been particularly concerned about this topic in lessons and exercises. The result shows that they consider it more important to choose an appropriate educational method rather than to expand and work on motivation.

The lowest standard deviation is presented in statement number 41, which is: I try very hard to use constructivism in primary science education, but sometimes I am inhibited by the school's conception (or the misunderstanding of management).

Table 7. Ranked statement number 41

\begin{tabular}{|l|l|l|l|l|l|l|l|l|l|l|l|l|l|l|l|l|l|l|}
\hline Respondents & 1 & 2 & 3 & 4 & 5 & 6 & 7 & 8 & 9 & 10 & 11 & 12 & 13 & 14 & 15 & PV & M & SD \\
\hline $\begin{array}{l}\text { Ranked } \\
\text { values }\end{array}$ & 5 & 5 & 5 & 5 & 5 & 2 & 5 & 4 & 5 & 5 & 5 & 5 & 5 & 3 & 5 & 5 & 4.600 & 0.910 \\
\hline
\end{tabular}

Legend 2: M...Mean, PV...Predicted value, SD...Standard deviation.

From Table 7 we can infer that Slovak students see the use of constructivism in practice in primary education as hard, because schools and their management may oppose alternative conceptions of primary science education. The result is that even though they would like to teach with constructivist principles in the future, they will probably not do so because of the policy of the school.

\subsubsection{Slovene Group}

The same analyses were done for the second group of respondents, the Slovene group. We searched for five statements that were ranked highest and five that were ranked lowest.

This group of respondents shows a high ranking of statements connected with teaching aids. For them it is very important to use a lot of versatile teaching aids, which are easily made from different material. Teaching aids are probably the study field which is emphasized in faculty lessons. Respondents show great inclination towards project work and other non-traditional methods of learning. Consequently they do not agree that the most effective 
way of learning is by observing teachers' proceedings. The lowest ranked statement represents a low affection for group work. In this case we should ask ourselves this: is it really an optimal way of teaching when the whole of primary science education is realized via group work? In comparison with the first group we can also find statement number 27 among the lowest ranked statements in this group.

The highest and the lowest standard deviation can also be found in this group. The highest standard deviation is presented in statement number 3, which is: If a teacher notices any incorrect thinking, he/she ought to correct it immediately.

Table 8. Five highest ranked statements in Slovene group of respondents

\begin{tabular}{|l|l|l|l|}
\hline Statement & $\begin{array}{l}\text { Predicted } \\
\text { value } \\
\text { category }\end{array}$ & Mean & St. deviation \\
\hline $\begin{array}{l}\text { 51. It is important to offer children as many } \\
\text { materials and aids for observing and } \\
\text { investigating as possible, because concrete } \\
\text { experience with materials is the most effective } \\
\text { educational method. }\end{array}$ & 6 & 7.867 & 1.995 \\
\hline $\begin{array}{l}\text { 70. The scientific method of reality } \\
\text { investigation is a natural learning method. } \\
\text { That is why the method is suitable for every } \\
\text { age. }\end{array}$ & 8 & 7.667 & 1.543 \\
\hline $\begin{array}{l}\text { 47. Project work helps children to develop } \\
\text { communication skills and also helps to foster } \\
\text { children's science ideas. Children also become } \\
\text { more self-confident and can justify their } \\
\text { thoughts, ideas and attitudes. }\end{array}$ & 6 & 7.333 & 1.799 \\
\hline $\begin{array}{l}\text { 50. Teaching aids are a necessary part of } \\
\text { primary science education. We can agree with } \\
\text { the statement about usage of aids: the more the } \\
\text { better. }\end{array}$ & 6 & 7.067 & 2.314 \\
\hline $\begin{array}{l}\text { 54. Words often cause incorrect views and a lot } \\
\text { of misunderstandings. That is why we need to } \\
\text { speak to primary pupils in their own language } \\
\text { - mainly via pictures, reality, aids, materials, } \\
\text { etc. It is not important to teach them how to } \\
\text { express their thoughts in a scientific way. }\end{array}$ & 6 & 1.642 \\
\hline
\end{tabular}


Table 9. Five lowest ranked statements in Slovak group of respondents

\begin{tabular}{|l|l|l|l|}
\hline Statement & $\begin{array}{l}\text { Predicted } \\
\text { value } \\
\text { category }\end{array}$ & Mean & $\begin{array}{l}\text { St. } \\
\text { deviation }\end{array}$ \\
\hline $\begin{array}{l}\text { 27. I cannot easily see a use for PC, internet, } \\
\text { encyclopedias and similar information sources } \\
\text { in contemporary primary science education. }\end{array}$ & 4 & 0.667 & 0.900 \\
\hline $\begin{array}{l}\text { 35. I use experiments to command pupils } \\
\text { attention and to motivate them for a following } \\
\text { activity. I think that in contemporary primary } \\
\text { science education, a better and more } \\
\text { sophisticated usage of an experimental method } \\
\text { is not possible. }\end{array}$ & 5 & 1.667 & 1.113 \\
\hline $\begin{array}{l}\text { 43. Whole primary science education should be } \\
\text { realized via group work. }\end{array}$ & 5 & 1.667 & 1.345 \\
\hline $\begin{array}{l}\text { 6. The most effective way to learn a lot in a } \\
\text { lesson is to observe teachers' proceedings. }\end{array}$ & 1 & 2.867 & 2.295 \\
\hline $\begin{array}{l}\text { l8. Science education is one of the most } \\
\text { difficult subjects at the primary level of } \\
\text { education, because pupils are unable to } \\
\text { understand the majority of commonly observed } \\
\text { phenomena in nature. That is why primary } \\
\text { science should be focused mainly on a } \\
\text { description and an observation of the } \\
\text { phenomena. }\end{array}$ & 3 & 3.200 & 2.513 \\
\hline
\end{tabular}

Table 10: Ranked statement number

\begin{tabular}{|l|l|l|l|l|l|l|l|l|l|l|l|l|l|l|l|l|l|l|}
\hline Respondents & 1 & 2 & 3 & 4 & 5 & 6 & 7 & 8 & 9 & 10 & 11 & 12 & 13 & 14 & 15 & PV & M & SD \\
\hline $\begin{array}{l}\text { Ranked } \\
\text { values }\end{array}$ & 9 & 2 & 8 & 8 & 9 & 9 & 5 & 2 & 9 & 0 & 5 & 4 & 7 & 3 & 7 & 0 & 5.800 & 3.028 \\
\hline
\end{tabular}

Legend 3: M...Mean, PV....predicted value, SD....standard deviation.

By sorting these statements we can conclude that students are not quite sure what to do when a pupil displays incorrect thinking. Following constructivist principles we should not correct him/her immediately but instead help to develop his/her ideas so s/he reaches the right conclusion. Respondent numbers 2,8,10 and 14 placed this statement in a lower category but on the other hand three respondents placed it in the highest categories.

The lowest standard deviation is presented in statement number 27, which is: I cannot easily see a use for PC, internet, encyclopedias and similar information sources in contemporary primary science education. 


\section{Macrothink}

Table 11. Ranked statement number 27

\begin{tabular}{|l|l|l|l|l|l|l|l|l|l|l|l|l|l|l|l|l|l|l|}
\hline Respondents & 1 & 2 & 3 & 4 & 5 & 6 & 7 & 8 & 9 & 10 & 11 & 12 & 13 & 14 & 15 & PV & M & SD \\
\hline $\begin{array}{l}\text { Ranked } \\
\text { values }\end{array}$ & 1 & 0 & 3 & 0 & 0 & 0 & 1 & 1 & 0 & 2 & 0 & 1 & 1 & 0 & 0 & 4 & 0.667 & 0.900 \\
\hline
\end{tabular}

Legend 4: M...Mean, PV....predicted value, SD....standard deviation.

Low standard deviation shows that data are not spread around so much. More than half of the students in this group do not agree with the statement, which means that they consider themselves as well able to see a use for information sources. Students are obviously well acquainted with information technology, which is probably a reason for the low mean.

\subsection{Correlation of Respondents'Attitudes and Factor Analysis}

To see if we could recognize any differences between the Slovene and Slovak groups and to find the level of attitude homogeneity in the respondent groups a correlation matrix was produced. The PQ Method program was used to count the data.

\subsubsection{Factor Matrix}

Table 12. Loadings of three factors

\begin{tabular}{|l|l|l|l|}
\hline \multicolumn{5}{|c|}{ Factor Matrix with X Indicating a Defining Sort } \\
\hline \multicolumn{5}{|c|}{ Loadings } \\
\hline QSORT & 1 & 2 & 3 \\
\hline 1 sk1 & $0.6460 X$ & 0.4325 & 0.0961 \\
\hline 2 sk2 & $0.6237 \mathrm{X}$ & 0.416 & -0.0304 \\
\hline 3 sk3 & 0.1785 & $0.7074 \mathrm{X}$ & 0.1772 \\
\hline 4 sk4 & 0.3701 & $0.6704 \mathrm{X}$ & -0.0589 \\
\hline 5 sk5 & 0.093 & $0.6380 \mathrm{X}$ & -0.0248 \\
\hline 6 sk6 & $0.5500 \mathrm{X}$ & 0.263 & 0.0583 \\
\hline 7 sk7 & $0.6745 \mathrm{X}$ & 0.4625 & -0.0391 \\
\hline 8 sk8 & 0.1356 & $0.7656 \mathrm{X}$ & 0.0474 \\
\hline 9 sk9 & 0.1009 & $0.7307 \mathrm{X}$ & 0.0452 \\
\hline 10 sk10 & $0.7016 \mathrm{X}$ & 0.2288 & -0.1144 \\
\hline 11 sk11 & $0.6806 \mathrm{X}$ & 0.3334 & -0.0152 \\
\hline 12 sk12 & -0.0403 & $0.5582 \mathrm{X}$ & 0.0821 \\
\hline 13 sk13 & 0.0275 & $0.4298 \mathrm{X}$ & 0.2147 \\
\hline 14 sk14 & -0.2373 & 0.1451 & 0.2722 \\
\hline 15 sk15 & $0.5404 \mathrm{X}$ & 0.2763 & 0.1294 \\
\hline 16 slo1 & 0.046 & 0.1237 & $0.6588 \mathrm{X}$ \\
\hline 17 slo2 & $0.5497 \mathrm{X}$ & -0.2268 & 0.3405 \\
\hline 18 slo3 & 0.3799 & -0.0078 & $0.5223 \mathrm{X}$ \\
\hline
\end{tabular}




\begin{tabular}{|l|l|l|l|}
\hline 19 slo4 & 0.2165 & 0.0707 & $0.4499 X$ \\
\hline 20 slo5 & -0.1162 & 0.0975 & $0.6280 X$ \\
\hline 21 slo6 & 0.2795 & 0.037 & $0.4738 X$ \\
\hline 22 slo7 & 0.2806 & -0.09 & $0.5424 X$ \\
\hline 23 slo8 & $0.6560 X$ & 0.1233 & 0.1778 \\
\hline 24 slo9 & 0.1364 & 0.2292 & $0.6962 X$ \\
\hline 25 slo10 & $0.5105 X$ & 0.0424 & 0.237 \\
\hline 26 slo11 & $0.4148 X$ & 0.1316 & 0.2639 \\
\hline 27 slo12 & $0.4497 X$ & 0.0025 & 0.2647 \\
\hline 28 slo13 & $0.5975 X$ & -0.0127 & 0.2686 \\
\hline 29 slo14 & $0.6113 X$ & -0.2233 & 0.2437 \\
\hline 30 slo15 & 0.4962 & -0.2079 & 0.4869 \\
\hline$\%$ expl. Var. & 19 & 14 & 11 \\
\hline
\end{tabular}

Table 13. Factor characteristics

\begin{tabular}{|l|c|c|c|}
\hline & \multicolumn{3}{|c|}{ Factors } \\
\hline & $\mathbf{1}$ & $\mathbf{2}$ & $\mathbf{2}$ \\
\hline No. of Defining Variables & 14 & 7 & 7 \\
\hline Average Rel. Coef. & 0.800 & 0.800 & 0.800 \\
\hline Composite Reliability & 0.982 & 0.966 & 0.966 \\
\hline S.E. of Factor Scores & 0.132 & 0.186 & 0.186 \\
\hline
\end{tabular}

Table 14. Standard Errors for Differences in Normalized Factor Scores

\begin{tabular}{|c|c|c|c|}
\hline Factors & $\mathbf{1}$ & $\mathbf{2}$ & $\mathbf{3}$ \\
\hline $\mathbf{1}$ & 0.187 & 0.228 & 0.228 \\
\hline $\mathbf{2}$ & 0.228 & 0.263 & 0.263 \\
\hline $\mathbf{3}$ & 0.228 & 0.263 & 0.263 \\
\hline
\end{tabular}

The program calculated three significant factors. The factor matrix summarizes which of the Q sorts are similar to or different from one another. That meant that we could find in our group of 30 students three significant points of view. The $\mathrm{x}$ standing with a number means significant loading. Other loadings are insignificant for that specific factor.

Especially interesting were group number 2 and group number 3, because significant loading for factors suggests that the second group was presented by respondents who were all from the Slovak group. The third group consisted originally of respondents from the Slovene group of students.

Standard errors for differences in normalized factor scores were needed subsequently to 
compare factors 2 and 3.

Analyses of factors and their distinctive statements were performed. For each factor we also calculated the ranking which group would award each statement. A different counting approach to our 11 categories was performed by a program. It evaluated categories with different numbers but the meaning and value of the category stayed the same.

\section{Factor 1}

The most distinctive statements for factor number 1 were calculated by the PQMethod program. We took a closer look at the first five statements defining this group:

1. Knowledge built up on the basis of own experimental activity is more stable in comparison with knowledge built up on the basis of secondary informational sources. (46).

2. Elementary schools should develop knowledge which is applicable to the environment children live in. The knowledge should help children to understand the life they live (58).

3. Experience learning should be one of the most preferred methods for science knowledge acquisition and for modification of science preconceptions (55).

4. The main role of a primary science teacher is to help pupils to analyse problems, investigate phenomena, ask questions and answer them via own experimental activity (69).

5. Primary pupils can produce hypotheses, but it is important to remember that they are able to create only hypotheses in connection with their own experience. Practically it means that children need to get as much experience about the investigated subject as possible (57).

The attitude of this group is closer to constructivism as a traditional concept of teaching primary science. Their attitude is definitely in favour of experimental activities and research work to help children construct knowledge on their own. They also understand teachers' role as helpers, not only wanting their children to learn hard and offering them answers without any activity. All these statements were ranked in the highest category of 10 or 9 . In program analyses we can read RNK numbers 5 and 4. Compared with the other two factors these statements were ranked in much lower categories.

\section{Factor 2}

First five distinctive statements for factor number 2:

1. If it is possible to demonstrate new knowledge by offering an object lesson, the best way to do this is a demonstration by the teacher (5).

2. Primary pupils are unable to obtain a great amount of knowledge. Often, however, they are unable to make the effort needed for knowledge acquisition. That is why motivation and repetition are so important. The chosen educational method is less important (25). 
3. A school should develop pupils'various abilities, skills and attitudes, but knowledge still holds first place (21).

4. A suitable educational environment offers pupils enough proper and valid knowledge. The knowledge is provided by a teacher, textbooks or other media. Pupils can get them by themselves, but in this case the teacher usually has to improve on the acquired knowledge (24).

5. It is important to offer children as many materials and aids for observing and investigating as possible, because concrete experience with materials is the most effective educational method (51).

Factor 2, which we conclude represents the attitude of the Slovak group of students, ranked encouraging teachers' demonstration highest. The role of motivation is highly grated. Other distinctive statements enlarge the role of the teacher. It is ranked quite high, since they highly ranked statement numbers 4 and 1. A positive attitude was also shown toward concrete experiences with materials as the most effective educational method. The factor differs from the other two factors in that educational environment is important.

Statement number 5 was highly ranked throughout.

\section{Factor 3}

First five distinctive statements for factor number 3:

1. Project work helps children to develop communication skills and also helps to accomplish children's science ideas. Children also become more self-confident and can justify their thoughts, ideas and attitudes (47).

2. The scientific method of reality investigation is a natural learning method. That is why it is suitable for every age (70).

3. Teaching aids are a necessary part of primary science education. We can agree with the statement about the usage of aids: the more the better (50).

4. Learning is an individual process whereby a pupil constructs new consequences out of read information, spoken information and especially own experience of real or simulated situations (74).

5. Pupils do not need to learn facts, but they have to be able to find them in various information sources (65).

Project work is considered as an appropriate method in primary science education. There is also a highly positive attitude towards teaching aids. These constitute statement numbers 47,70 and 50. These statements are reliable evidence that factor 3 presents the attitude of the Slovene group.

In conclusion, we present the most important aspects defining each factor in Table 15 below. 
Table 15. Important aspects defining three factors

\begin{tabular}{|c|c|c|c|}
\hline & Factor 1 & Factor 2 & Factor 3 \\
\hline $\begin{array}{l}\text { Important } \\
\text { aspects } \\
\text { defining } \\
\text { factor }\end{array}$ & $\begin{array}{l}\text { - Children's own } \\
\text { experimental activity } \\
\text { and experimental } \\
\text { learning. } \\
\text { - Teacher's role is to } \\
\text { help analyse problems } \\
\text { and orient children } \\
\text { towards solutions. } \\
\text { - Children are able to } \\
\text { make hypotheses in } \\
\text { connection with their } \\
\text { own experience. } \\
\text { - Use of the children's } \\
\text { knowledge in everyday } \\
\text { life in the environment } \\
\text { they live in. }\end{array}$ & $\begin{array}{l}\text { - Teacher has an } \\
\text { important role. } \\
\text { - Motivation is } \\
\text { important. } \\
\text { - Concrete } \\
\text { experiences with } \\
\text { materials. } \\
\text { - Suitable } \\
\text { educational } \\
\text { environment. }\end{array}$ & $\begin{array}{l}\text { - Project work. } \\
\text { - Scientific } \\
\text { method can be } \\
\text { applied at every } \\
\text { age. } \\
\text { - Teaching aids. } \\
\text { - Ability to find } \\
\text { information } \\
\text { sources. }\end{array}$ \\
\hline
\end{tabular}

Table 16. Factor arrays

\begin{tabular}{|l|l|l|l|l|}
\hline \multicolumn{5}{|c|}{ Descending Array of Differences Between Factors 2 and 3 } \\
\hline No. & Statement & Type 2 & Type 3 & Difference \\
\hline 43 & 43 & 1.045 & -2.241 & 3.286 \\
\hline 35 & 35 & -0.014 & -2.689 & 2.675 \\
\hline 5 & 5 & 1.775 & -0.646 & 2.421 \\
\hline 52 & 52 & 0.651 & -1.712 & 2.362 \\
\hline 37 & 37 & 0.675 & -1.477 & 2.152 \\
\hline
\end{tabular}

For the purpose of our research another interesting element is the differences between factors 2 and 3, since we consider that factor 2 defines the Slovak group and factor 3 the Slovene group. The first five statements with the highest level of factor differences are presented below.

Statements:

1. Whole primary science education should be realized via group work (43).

2. I use experiments to command pupils' attention and to motivate them for a following activity. I think that in contemporary primary science education, a better and more sophisticated usage of an experimental method is not possible (35).

3. If it is possible to demonstrate new knowledge by offering an object lesson, the best way to do this is a demonstration by the teacher (5). 
4. Prompting questions in a primary science lesson is to a certain extent a measure of children's interest, curiosity and motivation. Teachers should develop the ability to ask questions, so the children ask questions suitable for further investigation in the science lesson (52).

5. I would like to use various methods in primary science education, but the curriculum is restrictive (37).

We can conclude that these are statements on which the groups' views are completely different.

The primary education science categories which divide students into groups are:

- attitude towards group work;

- usage of experimental methods;

- teachers' demonstration;

- suitable questions;

- strict curriculum in relation to teaching methods.

\section{Discussion}

With the help of factor analysis we defined three groups, which were implicit in the structure of the intercorrelation matrix. Correlations are quite low, but they are high enough to predict even the weakest correlation between respondents.

After analyzing and interpreting factors we established that factor 1 captures all students' attitudes, factor 2 Slovak students and factor 3 Slovene students. We found that students prefer a constructive approach to learning and teaching science.

The best way to support our finding is to summarize data from factor 1 which represents both groups of students. Considering the highly ranked statements, we can conclude that attitude of both groups is proven closer to constructivism as a traditional concept of teaching primary science. Since experimental activities and research work help children to construct knowledge on their own it can be considered as the main principle of constructivism.

Furthermore, differences between the Slovak and Slovene groups are striking. Since each group represents one factor it can be deduced that q statements were significantly different as a result of various influences. These influences are evident in the curriculum specifics. Each faculty has a different number of hours for and arrangement of study subjects.

By pointing out the most obvious bone of contention we can reveal the role of the teacher. The Slovak group considered the teacher as somebody who demonstrates and frontally explains new knowledge. Slovene students did not agree that the most effective way of learning is by observing teachers' proceedings. They showed great inclination for project work and other non-traditional methods of learning. Even though the groups did not agree about the teacher's role in the process of education their opinions coincided on another important aspect of teaching science. Both groups agreed that it is important to use different study materials in many different environments. Slovak students in particular showed great 
inclination for appropriate and interesting classrooms, one of the applications of constructivism theory in praxis.

As far as forms of learning go, Slovak students preferred group learning and Slovene students preferred projects, as mentioned above.

\section{Conclusion}

There are proven specific differences between groups which are probably associated with many factors such as curriculum, age, hours of classes and study environment, but these differences are all to do with positive attitudes toward the constructivist approach to primary science education.

Constructivism represents one of the biggest ideas in education. Its implications for teachers' teaching and learning to teach are immense. It is important that students get to know different aspects of learning. Teachers cannot teach according to constructivism principles if they do not know enough about them. The process of teaching primary science education can only be mastered when the teacher knows what to teach and how to teach.

\section{References}

Brown, S. R. (1996). Q methodology and qualitative research. Qualitative Health Research, 6, 561-567.

Bruner, J. (1980). Actual minds, possible worlds. Cambridge, MA: Harvard University Press.

Cakir, M. (2008). Constructivist approaches to learning in science and their implications for science pedagogy: A literature review. International Journal of Environmental \& Science Education, 3(4), 193-206.

Hickman, L.A., Neubert, S., \& Reich, K. (2009). John Dewey between pragmatism and constructivism. New York, NY: Fordham University Press.

Hmelo-Silver, C. E., \& Barrows, H. S. (2006). Goals and strategies of a problem-based learning facilitator. Interdisciplinary Journal of Problem-based Learning, 1, 21-39.

Lamanauskas, V. (2007). Some features of initial science teacher training in Lithuania. Problems of Education in 21st Century, 2, 45-53.

Papert, S. (1980). Mindstorm: children, computers, and powerful ideas. New York, NY: Basic Books.

Science Education in Europe. (2011). National policies, practice and research. Brussels: Education, Audiovisual and Culture Executive Agency.

Šorgo, A., \& Kocijančič, S. (2011). Presentation of laboratory sessions for science subjects in Slovenian upper secondary schools. J. Balt. Sci. Educ., 2, 98-113.

Šorgo, A., Lamanauskas, V., Šimić Šašić, S., Kubiatko, M., Prokop P., Frančovičova, J., ... Erdogan, M. (2012). A cross-national study of prospective elementary and science teachers' creativity styles. J. Balt. Sci. Educ., 3, 285-292. 
Vygotsky, L. S. (1978). Mind in society: The development of higher psychological processes. Cambridge, MA: Harvard University Press.

Wertsch, J. V. (1985) Vygotsky and the social formation of mind. Cambridge, MA: Harvard University Press.

Wigger, U., \& Mrtek, R. G. (1994). Use of Q-technique to examine attitudes of entering pharmacy students toward their profession. American Journal of Pharmaceutical Education, $58,8-15$.

Wilson, B. G. (1996). Constructivist learning environments: Case studies in instructional design. Englewood Cliffs, NJ: Educational Technology.

Žoldošová, K. (2008): Cielená zmena preferovanej učitelovej koncepcie vyučovania $v$ primárnom prírodovednom vzdelávaní smerom $k$ výskumne ladeným koncepciám, Pedagogický výzkum jako podpora proměny současné školy (Sborník sdělení 16. konference ČAPV), Pedagogická fakulta UHK, Hradec Králové, str. 674-686.

\section{Copyright Disclaimer}

Copyright reserved by the author(s).

This article is an open-access article distributed under the terms and conditions of the Creative Commons Attribution license (http://creativecommons.org/licenses/by/3.0/). 